\title{
Neuronal Differentiation in Schwann Cell Lineage Underlies Postnatal Neurogenesis in the Enteric Nervous System
}

\author{
(1)Toshihiro Uesaka, ${ }^{1,2,3}{ }^{\circledR}$ Mayumi Nagashimada, ${ }^{2}$ and ${ }^{\circ H}$ Hideki Enomoto ${ }^{1,2,3}$ \\ ${ }^{1}$ Division of Neural Differentiation and Regeneration, Department of Physiology and Cell Biology, Graduate School of Medicine, Kobe University, Kobe \\ 650-0017, Japan, ${ }^{2}$ Laboratory for Neuronal Differentiation and Regeneration, RIKEN Center for Developmental Biology, Kobe 650-0047, Japan, and ${ }^{3}$ Core \\ Research for Evolutional Science and Technology, Japan Science and Technology Agency, Saitama 332-0012, Japan
}

\begin{abstract}
Elucidation of the cellular identity of neuronal precursors provides mechanistic insights into the development and pathophysiology of the nervous system. In the enteric nervous system (ENS), neurogenesis persists from midgestation to the postnatal period. Cellular mechanism underlying the long-term neurogenesis in the ENS has remained unclear. Using genetic fate mapping in mice, we show here that a subset of Schwann cell precursors (SCPs), which invades the gut alongside the extrinsic nerves, adopts a neuronal fate in the postnatal period and contributes to the ENS. We found SCP-derived neurogenesis in the submucosal region of the small intestine in the absence of vagal neural crest-derived ENS precursors. Under physiological conditions, SCPs comprised up to $20 \%$ of enteric neurons in the large intestine and gave rise mainly to restricted neuronal subtypes, calretinin-expressing neurons. Genetic ablation of Ret, the signaling receptor for glial cell line-derived neurotrophic factor, in SCPs caused colonic oligoganglionosis, indicating that SCP-derived neurogenesis is essential to ENS integrity. Identification of Schwann cells as a physiological neurogenic source provides novel insight into the development and disorders of neural crest-derived tissues.
\end{abstract}

Key words: enteric nervous system; neural crest cells; neurogenesis; oligoganglionosis; RET; Schwann cells

Significance Statement

Elucidating the cellular identity of neuronal precursors provides novel insights into development and function of the nervous system. The enteric nervous system (ENS) is innervated richly by extrinsic nerve fibers, but little is known about the significance of extrinsic innervation to the structural integrity of the ENS. This report reveals that a subset of Schwann cell precursors (SCPs), which invades the gut alongside the extrinsic nerves, adopts a neuronal fate and differentiates into specific neuronal subtypes. SCP-specific ablation of the Ret gene leads to colonic oligoganglionosis, demonstrating a crucial role of SCP-derived neurogenesis in ENS development. Cross-lineage differentiation capacity in SCPs suggests their potential involvement in the development and pathology of a wide variety of neural crest-derived cell types.

\section{Introduction}

The exquisite architecture and function of the nervous system arises from neurogenesis, which generates distinct neuronal

Received March 31, 2015; revised May 26, 2015; accepted June 1, 2015.

Author contributions: T.U. and H.E. designed research; T.U. performed research; M.N. contributed unpublished reagents/analytic tools; T.U. and H.E. analyzed data; T.U. and H.E. wrote the paper.

This work was supported by RIKEN, Ministry of Education, Culture, Sports, Science, and Technology Science Research Funds Grant 2212005, Japan Society for the Promotion of Science Grant 25460279, the Naito Foundation, and the Core Research for Evolutional Science and Technology, Japan Science and Technology Agency. We thank Prof. Dies Meijer (University of Edinburgh, Edinburgh, Scotland) for providing us Dhh:: Cre mice, the Laboratory for Animal Resources and Genetic Engineering for their excellent technical assistance, and T. Hirai for help with targeting vector construction. We also are grateful to D. Sipp for editing this manuscript.

The authors declare no competing financial interests.

Correspondence should be addressed to Hideki Enomoto, Division of Neural Differentiation and Regeneration, Department of Physiology and Cell Biology, Graduate School of Medicine, Kobe University, Kobe 650-0017, Japan. E-mail:enomotoh@med.kobe-u.ac.jp.

M. Nagashimada's present address: Department of Cell Metabolism and Nutrition, Brain/Liver Interface Medicine Research Center, Kanazawa University, Kakuma-machi, Kanazawa, Ishikawa 920-1192, Japan. classes at appropriate developmental time periods. Elucidation of the cellular identity of neuronal precursors that contribute to a given neuronal population is vital toward our understanding of the development and pathology of the nervous system.

The enteric nervous system (ENS) is the largest and most complex division of the peripheral nervous system and displays robust neurogenesis. During development, neural crest cells at the vagal and sacral levels (Le Douarin and Teillet, 1973; Le Douarin and Kalcheim, 1999) invade the gut wall, become enteric neural crest-derived cells (ENCCs), and undergo migration along the gut wall, ultimately integrating into the entire length of the gut (Anderson et al., 2006; Nishiyama et al., 2012; Obermayr et al., 2013). During their migration, some ENCCs begin to differentiate into neurons, which is detectable as early as embryonic 
Table 1. Summary of parental crosses and offspring used for the experiments

\begin{tabular}{|c|c|c|c|c|}
\hline Parental cross & Genotype of the offspring & Marker & Figures & References \\
\hline $\operatorname{Ret}^{G F P /+} \times \operatorname{Ret}^{G F P /+}$ & $\operatorname{Ret}^{G F P / G F P}$ & Ret (GFP) & 1 & $a$ \\
\hline Gfr $\alpha 1^{G F P /+} \times G f r \alpha 1^{+/+}$ & Gfr $\alpha 1^{G F P /+}$ & Gfr $\alpha 1$ (GFP) & $2 B, C$ & $b$ \\
\hline Gfr $\alpha 7^{f-G F P /+} \times$ Dhh::Cre & Gfr $\alpha t^{f-G F P /+} /$ Dhh::Cre & Gfr $\alpha 1$ (GFP) & $2 B, C$ & $b, c$ \\
\hline Gfr $\alpha 7^{f l-G F P /+} \times$ Dhh::Cre & Gfr $\alpha 7^{f l-G F P /+} / D h h:: C r e$ & Gfr $\alpha 1$ (GFP) & $4,5,7$ & $b, c$ \\
\hline $\operatorname{Ret}^{f l-C F P /+} \times D h h:: C r e$ & $\operatorname{Ret}^{f l-C P P /+} / D h h:: C r e$ & Ret (CFP) & 6,8 & $c, e$ \\
\hline $\operatorname{Ret}^{f l-C F P / f f-C F P} \times \operatorname{Ret}^{+/-} /$Dhh $:: C r e$ & $\operatorname{Ret}^{f-C F P /+} / D h h:: C r e$ (control) & Not used & 9 & $c, e, f$ \\
\hline
\end{tabular}

Jain et al., 2006.

bUesaka et al., 2007.

'Jaegle et al., 2003.

${ }^{d}$ Enomoto et al., 1998.

eUesaka et al., 2008.

${ }^{f}$ Gould et al., 2008.

day 10.5 (E10.5) to E11.5 in mice (Rothman and Gershon, 1982, 1984; Branchek and Gershon, 1989; Young et al., 2002). Neurogenesis continues throughout later developmental time periods and persists even after the postnatal period (Pham et al., 1991; Wang et al., 2010; Laranjeira et al., 2011). Such long-term maintenance of neurogenic potential in neural progenitors is unique to the ENS among the all divisions of the peripheral nervous system. However, to date, the developmental mechanism underlying this persistent neurogenesis in the ENS has remained unclear.

Although the basic ganglion structure of the ENS develops via intrinsic innervation by ENCC-derived neurons, the gut also receives robust extrinsic innervation, which occurs late in development. A large numbers of Schwann cell precursors (SCPs) invade and populate the gut wall alongside the extrinsic nerve fibers, but the role of these SCPs in the structural integrity of the ENS is undetermined. Recent genetic tracing experiments in early developing mouse embryos (at approximately E11) demonstrated that cranial nerve-associated neural progenitor cells of the parasympathetic ganglia express markers for SCPs (Dyachuk et al., 2014; Espinosa-Medina et al., 2014). Another study showed that Schwann cells isolated from adult sciatic nerves display neural crest stem cell-like multipotency and differentiate into neurons, glia, and smooth muscle cells in culture (Widera et al., 2011). These findings raise the possibility that neurogenesis involving SCPs is not restricted to early development and may represent a more general phenomenon. The extent of SCP-derived neurogenesis in vivo and its potential influence on the development of the nervous system remains open questions.

In this study, we hypothesized that SCP-derived neurogenesis may underlie long-term neurogenesis in the ENS. To address this issue, we followed the fate of SCPs in the gut by genetic tracing. Here we provide evidence that SCPs exhibit neurogenic potential and contribute to postnatal neurogenesis in the ENS. SCPderived neurons constitute a significant part of the ENS; the majority of such neurons differentiate into a restricted neuronal subtype expressing calretinin. Inactivation of RET, the signaling receptor of GDNF, in SCPs causes a significant reduction in the number of enteric neurons in the distal colon, indicating the physiological requirement of SCP-derived neurons in the ENS structure. This study reveals the widespread and long-term maintenance of SCP-derived neurogenesis, which may open up new avenues into understanding the pathogenesis of the peripheral nervous system and the development of biomedical technologies, such as SCP-based neural tissue engineering.

\section{Materials and Methods}

Mouse strains. The generation and characterization of Gfr $\alpha 1^{f l-G F P}$, $\operatorname{Ret}^{f l-C F P}$, and $\operatorname{Ret}^{-}$mice have been described previously (Uesaka et al., 2007, 2008; Gould et al., 2008). We obtained Ret ${ }^{\text {GFP }}$ (Jain et al., 2006) and Gfr $\alpha 1^{-1-}$ mice (Enomoto et al., 1998; kind gifts from J. Milbrandt, Washington University School of Medicine, St. Louis, MO) and Dhh::Cre mice (kind gift from D. Meijer, University of Edinburgh, Edinburgh, Scotland; Jaegle et al., 2003).

Breeding and genotyping of mice. Most mice (Mus musculus) used for this study were on a C57BL/6-129Sv mixed background and both sexes. Ret $^{G F P}$ mice have been backcrossed to C57BL/ 6 for $>10$ generations. All mice were maintained on a $12 \mathrm{~h}$ light/dark cycle with water and food available ad libitum and housed either singly or in groups. A maximum of five adult animals per cage were allowed. The various breeding schemes were summarized in Table 1. All animal experiments were approved by the Animal Research Committee of the RIKEN Center for Developmental Biology and were performed in accordance with RIKEN guidelines for animal and recombinant DNA experiments. For routine genotyping, we performed PCR amplification of DNA prepared from tail.

Immunohistochemistry. Tissues were fixed in $4 \%$ paraformaldehyde/ $\mathrm{PBS}$ at $\mathrm{pH}$ 7.4. Immunohistochemistry experiments were performed as described previously (Uesaka et al., 2013). For whole-mount staining, the preparations were incubated in 1\% Triton X-100 for 30 min before immunostaining. Primary antibodies were chosen according to previous studies in our laboratory, reports in the literature, or instructions from the vendors. We identified variants of GFP and CFP by chicken anti-GFP (1:1000; GFP-1010; Aves Labs), and secondary antibodies used were Alexa Fluor 488 goat anti-chicken IgY (1:500; A-11039; Life Technologies). The following antibodies were also used: rabbit anti-protein gene product 9.5 (PGP9.5; 1:1000; RA95101; UltraClone), goat anti-Sox10 (1:400; sc-17342; Santa Cruz Biotechnology), mouse anti-TuJ1 (1:500; MMS435P; Covance), rabbit anti-brain lipid binding protein (BLBP; 1:500; AB9558; Millipore), rabbit anti-Phox2b (1:1000; a gift from J.-F. Brunet, National Center for Scientific Research, Paris, France), rabbit anti-Cre (1:400; PRB-106P; Covance), mouse anti-synaptic vesicle protein 2 (SV2; 1:100; Developmental Studies Hybridoma Bank), rabbit anti-calretinin (1:2000; AB5054; Millipore), and rabbit anti-neuronal nitric oxide synthase (NOS) (1:500; AB5380; Millipore). We used appropriate secondary antibodies (1:500) conjugated to Alexa Fluor 488, Alexa Fluor 594, and Alexa Fluor 647 (Invitrogen) and CF568 and CF640R (Biotium). We took photomicrographs using a Zeiss LSM5 PASCAL confocal microscope, a Zeiss Axioskop 2 FS plus with a digital camera AxioCam HRc, or a Leica MZ FLIII with a digital camera AxioCam MRc5. Representative images were selected from animals or experiments that had been repeated at least three times.

Cell culture. For primary culture of SCPs, the gut mesenteries dissected from Dhh::Cre/Gfr $\alpha 1^{f l}$-GFP mouse embryo at E16.5 were treated with collagenase/dispase ( $1 \mathrm{mg} / \mathrm{ml}$; Roche) for $10 \mathrm{~min}$ at $37^{\circ} \mathrm{C}$. The cells were dissociated by repeated pipetting, and cells were filtered through $35 \mu \mathrm{m}$ 
A

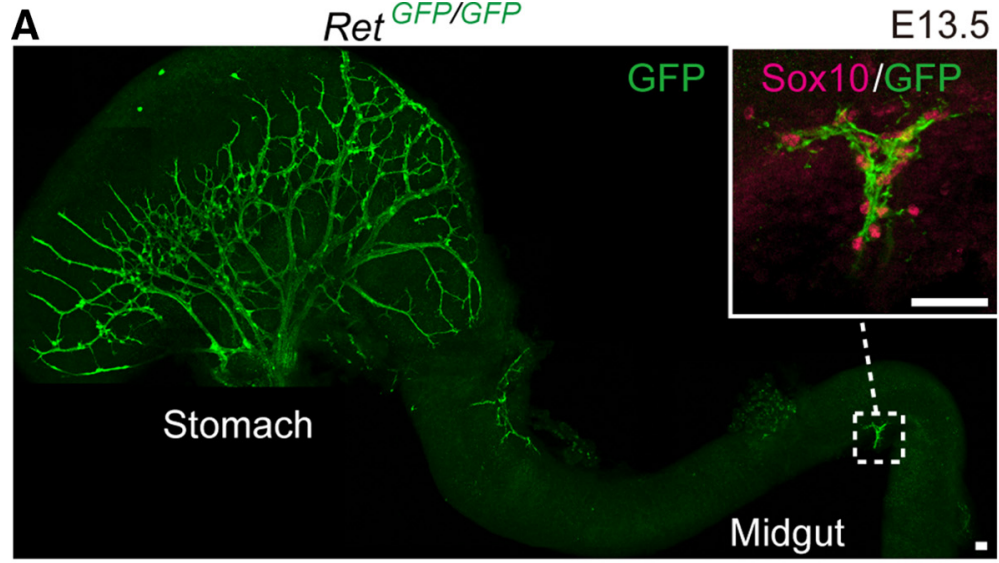

B

Stomach

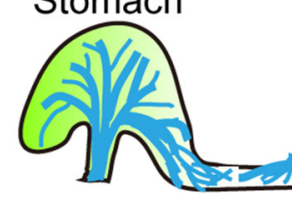

Ret $^{\text {GFP/GFP }}$

(submucosal region)

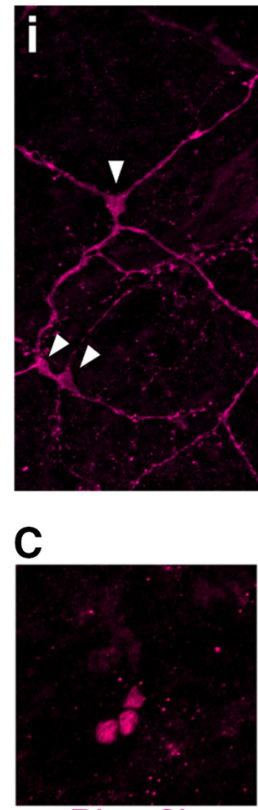

Phox2b

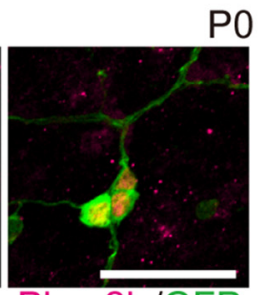

Phox2b/GFP

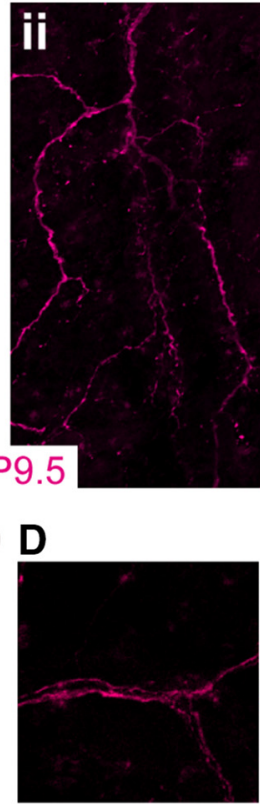

$\mathrm{TH}$

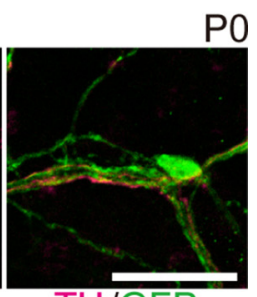

TH/GFP

Figure 1. Enteric neurogenesis occurs without vagal ENCCS. A, Whole-mount GFP (green) staining of the gastrointestinal tract from E13.5 Ret-deficient (Ret $\left.{ }^{G F P / G F P}\right)$ embryos $(n=3)$. Higher magnification (inset) shows the presence of Sox $10^{+} \mathrm{SCPs}$ along the extrinsic nerve bundles. $\boldsymbol{B}$, Top, Schematic diagram illustrating the stomach and the locations of extrinsic nerve fibers. Bottom, Representative images of the submucosal region in $\operatorname{Ret}^{G F P / G F P}$ small intestine $(\boldsymbol{i}, \boldsymbol{i} i)$, showing expression of PGP9.5 (magenta; white arrowheads in iand $i i, n=3$ ). C, Whole-mount GFP (green) and Phox $2 b$ (magenta) staining of the submucosal region in Ret ${ }^{G F P / G F P}$ duodenum $(n=3)$. $\boldsymbol{D}$, Submucosal neurons in $\operatorname{Ret}^{\text {GFP/GFP }}$ mice $(n=3)$ associated with tyrosine hydroxylase-positive $\left(\mathrm{TH}^{+}\right)$ sympathetic nerve fibers (magenta). Scale bars, $50 \mu \mathrm{m}$.

nylon mesh. Next, SCPs were immunoselected with $5 \mu \mathrm{g}$ of mouse antiP75 ${ }^{\text {NTR }}$ (ab61425; Abcam) and anti-mouse IgG MicroBeads (130-048402; Miltenyi Biotec), following the instructions of the manufacturer. After immunoselection, the cell suspension was centrifuged and washed with PBS, and $\sim 1 \times 10^{3}$ cells were resuspended in neurosphere medium consisting of DMEM/Ham's F-12 (Wako) containing $20 \mathrm{ng} / \mathrm{ml}$ recombinant human bFGF (R\&D Systems), 20 ng/ml IGF1 (R\&D Systems), 1\% $\mathrm{N} 2$ supplement (Invitrogen), 2\% B27 supplement (Invitrogen), $50 \mathrm{~mm}$ 2-mercaptoethanol, $15 \%$ chick embryo extract, $35 \mathrm{mg} / \mathrm{ml}$ retinoic acid
(Sigma-Aldrich), and penicillin and streptomycin (P/S; Meiji) in nonadhesive culture plates treated with F127 (Sigma-Aldrich). After overnight culture, cells were plated onto a single well of an eight-well side coated with polyD-lysine $(0.1 \mathrm{mg} / \mathrm{ml}$; Sigma-Aldrich) and 0.15 $\mathrm{mg} / \mathrm{ml}$ human fibronectin (Biomedical Technologies). Neurogenesis was observed after $5 \mathrm{~d}$ in DMEM-low (Invitrogen) containing 2\% B27 and 1\% N2 supplement, $100 \mathrm{ng} / \mathrm{ml}$ GDNF (R\&D Systems), and P/S. Primary culture of enteric neurons from Dhh::Cre/Gfr $\alpha 1^{f l}$-GFP midgut was prepared as described previously (Uesaka et al., 2007).

Statistical analyses. Statistical analyses were performed by use of GraphPad Prism 5.04 software (GraphPad Software). No statistical methods were used to predetermine sample sizes, but our sample sizes are similar to those reported in previous studies (Nishiyama et al., 2012; Uesaka et al., 2013) and generally used in the field. No data points were excluded from all experiments. No randomization of samples was performed. Quantification of total neuron number in the terminal colon of control and conditional knock-out (cKO; Dhh:: Cre/Ret ${ }^{f l-C F P /-}$ ) were done blind. No blinding was done in other experiments. The similarity of variances between each group of data was tested using the $F$ test. Statistical analysis was performed using unpaired two-tailed $t$ test with Welch's correction. Results are expressed as mean \pm SEM.

\section{Results}

Enteric neurogenesis is detectable in the absence of intrinsic innervation by ENCCs

The primary ganglion structure of the ENS develops through intrinsic innervation by ENCCs. These cells migrate extensively along the gut wall during development, and their survival, migration, and proliferation depend on GDNF signaling via the RET/GFR $\alpha 1$ receptor complex. Mice deficient for Gdnf, Ret, or Gfr $\alpha 1$ lack all ENCC-derived intrinsic innervation in the small and large intestine (Durbec et al., 1996; Fig. 1A). However, contrary to the current consensus that all enteric neurons are derived from ENCCs, our close examination of the small intestine of Ret- or Gfr 1 1-deficient embryos detected some neurons during the perinatal period (Fig. $1 B, C$ ). Those neurons were detected only in the submucosal layer, always in association with the extrinsic nerves (Fig. 1D), in numbers ranging from 13 to 83 cells/gut $(n=16)$. No neurons were detected in gut regions in which the extrinsic nerves were few or absent. Notably, the regions of the small intestine that contained neurons were interrupted by aganglionic gut segments and often located far distal to the stomach (Fig. 1B). Because ENCCs migrate as a chain to colonize the gut (Young et al., 2004; Druckenbrod and Epstein, 2005) and because ENCCs stop their migration and die in the rostral part of the foregut in the absence of RET signaling 
(Taraviras et al., 1999), it is unlikely that neurons in the small intestine found in Ret- or Gfra1-deficient embryos are derived from ENCCs. These data collectively indicate that, albeit not robust, neurogenesis does occur in the absence of ENCCs and that the neurogenesis is always associated with extrinsic nerves (Fig. 1D).

Because SCPs invaded Ret-deficient small intestine along the extrinsic nerves around midgestation (Figs. $1 A$, inset, $2 A$ ), we hypothesized that neurons identified in ENCC-free gut are derived from SCPs. To test this possibility, we genetically traced SCPs by Cre-loxP technology using the Dhh-Cre driver line (Jaegle et al., 2003). Dhh is expressed prominently in SCPs and Schwann cells and controls the formation of the connective tissue sheath around peripheral nerves (Bitgood and McMahon, 1995; Parmantier et al., 1999). We first validated SCP-specific labeling by crossing a Dhh::Cre line to a Gfr $\alpha 1^{f l-G F P /+}$ reporter mouse line (Uesaka et al., 2007; Fig. $2 B$, bottom). Although Gfr $\alpha 1$ is normally expressed in both SCPs and ENCCs (Fig. $2 B, C$, top panels), in the compound animal, GFP reporter expression was detected in only SCPs but not in ENCCs (Fig. $2 B, C$, bottom panels), confirming SCP-specific cell labeling by the Dhh::Cre driver (Joseph et al., 2004; Wong et al., 2006). To examine whether neurons in ENCC-free gut are derived from SCPs, we generated mice harboring a Dhh::Cre transgene (Jaegle et al., 2003) and Ret ${ }^{f l}$ CFP reporter allele $\left(\operatorname{Ret}^{f l-C F P /+}\right.$; Uesaka et al., 2008) on a Gfra1-deficient background (Fig. $3 A$ ). The Ret $t^{f l-C F P /+}$ reporter allele labels all enteric neurons and their precursors by CFP after Cre-loxP recombination, thus serving as the most sensitive reporter of SCP-derived enteric neurogenesis. We found that all submucosal neurons $\left(\mathrm{PGP} .5^{+}\right)$detected in Gfr $\alpha 1$-deficient small intestine expressed CFP (Fig. 3B). The data strongly suggest that neurons in ENCC-free gut are derived from SCPs.

\section{SCP-derived neurons physiologically contribute to the ENS}

The observation of Dhh::Cre-labeled neurons in Ret- and Gfrol-deficient mice prompted us to investigate whether SCPderived neurogenesis takes place in the presence of ENCCs. To address this issue, we first examined the normal distribution pattern of SCPs in the gut using mouse embryos harboring the Dhh::Cre driver and Gfr $\alpha 1^{f l-G F P /+}$ reporter. $\mathrm{GFP}^{+}$SCPs invaded the wall of the small intestine at approximately E14.5 (Fig. 4A). All GFP ${ }^{+}$
A Extrinsic efferent and

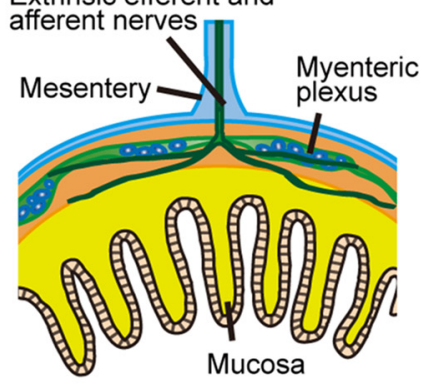

B
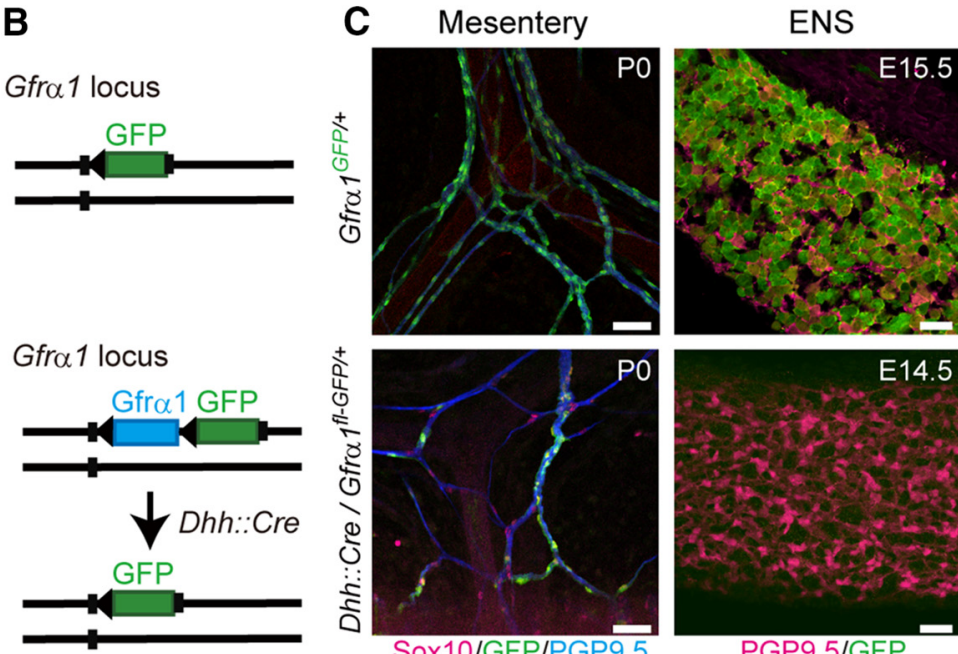

Sox10/GFP/PGP9.5

PGP9.5/GFP

Figure 2. SCPs are labeled selectively by GFP in Dhh::Cre/Gfr $\alpha 7^{f t}-G F P$ mice. $A$, Schematic diagram showing extrinsic nerve fibers projecting to the gut at E14.5. B, Schematic representation of Gfr $\alpha 1$-GFP knock-in allele for the Gfr $\alpha 7^{f l}-G F P$ reporter (top) and genetic tracing of SCPs by Dhh.:: (re and Gfr $\alpha 7^{f l}-G F P$ reporter line (bottom). C, Gfr $\alpha 1$ promoter drives GFP expression in both SCPS along the extrinsic nerves (top left) and ENS cells (top right) in Gfr $\alpha 7^{G F P /+}$ mice $(\mathrm{PO}, n=3 ; \mathrm{E} 15.5, n=3)$. Dhh:::Cre-mediated GFP labeling was detected in $\mathrm{SCPS}\left(\mathrm{Sox}_{10}{ }^{+}\right.$) within the mesentery (bottom left, $n=3$ mice), whereas GFP signals were not detected in vagal NC-derived enteric neurons (PGP9.5 ${ }^{+}$) at E14.5 (bottom right, $n=3$ ). Scale bars, $50 \mu \mathrm{m}$.

A $_{\text {Gra } 1^{-/-} / D h h:: C r e / R e t}{ }^{\text {fl-CFP/+ }}$
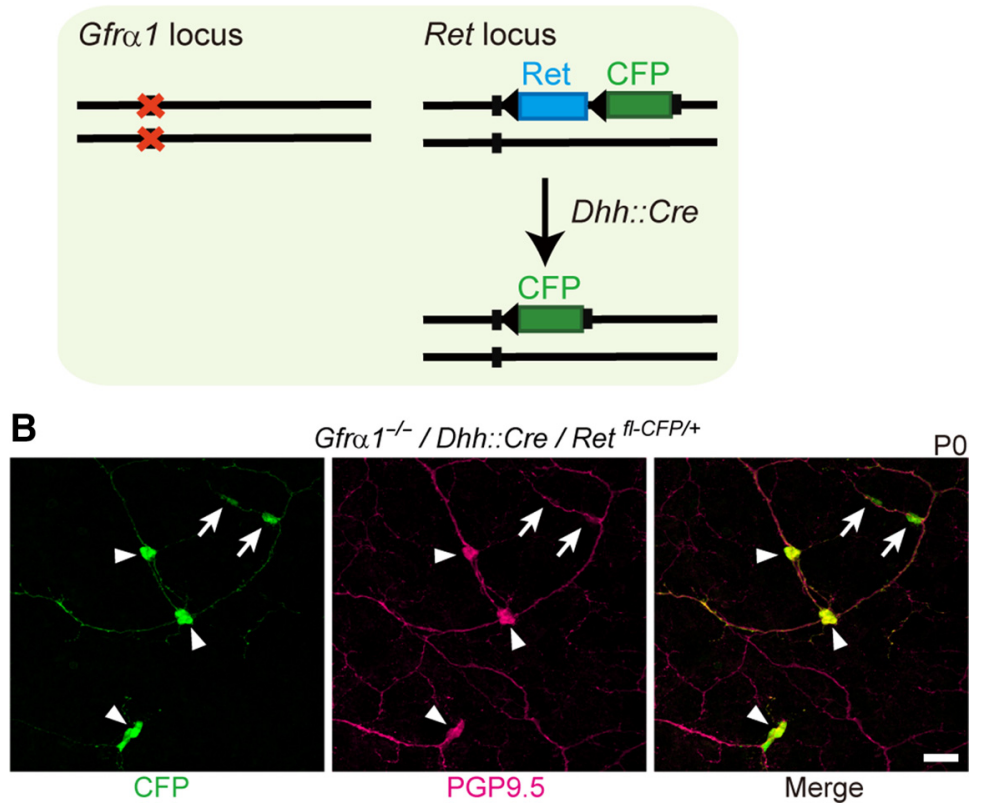

Figure 3. Enteric neurons in Gfr $\alpha 1$-deficient small intestine are labeled by the Dhh::Cre driver. $A$, Schematic showing genetic tracing of SCPs in Gfr $\alpha 1$-deficient mice by the Dhh::Cre driver. B, Confocal images of Gfr $\alpha 1$-deficient small intestine (Dhh::Cre/Ret ${ }^{f-C F P /+} / \mathrm{Grr} \alpha 1^{-1-}, n=3$ ) showing the presence of GFP ${ }^{+}-\mathrm{PGP} 9.5^{+}$neurons (arrowheads) in the submucosal region. Small arrows depict GFP ${ }^{+}$-PGP9. $5^{-}$cells. Scale bar, $50 \mu \mathrm{m}$. 


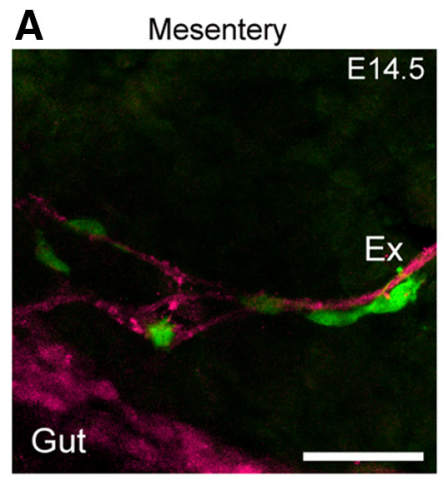

GFP/PGP9.5

\section{Myenteric plexus}

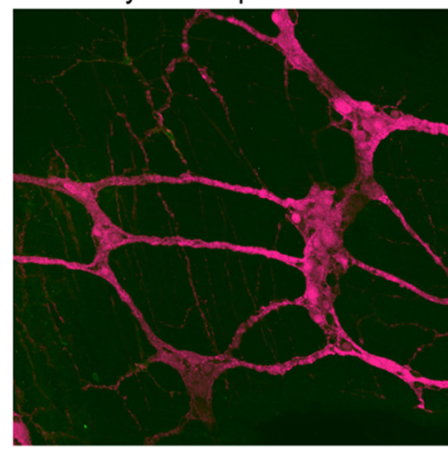

D

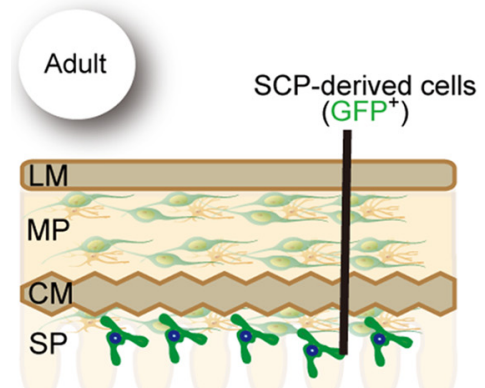

B

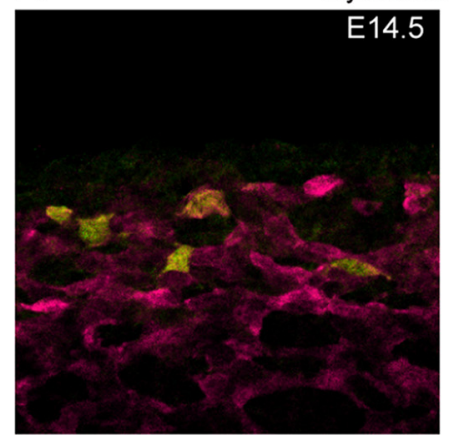

GFP/BLBP

Deep muscular plexus

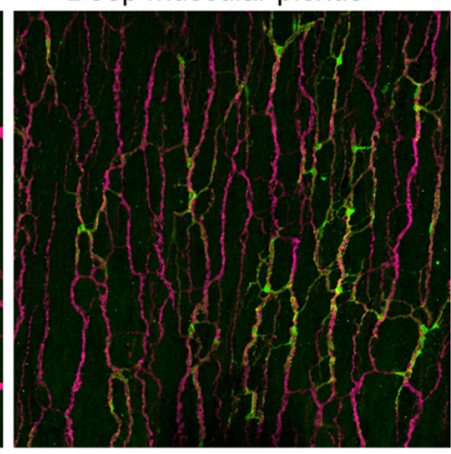

GFP/PGP9.5
Myenteric plexus

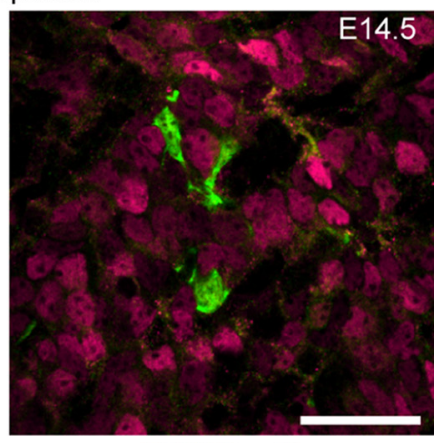

GFP/Phox2b

Submucosal plexus

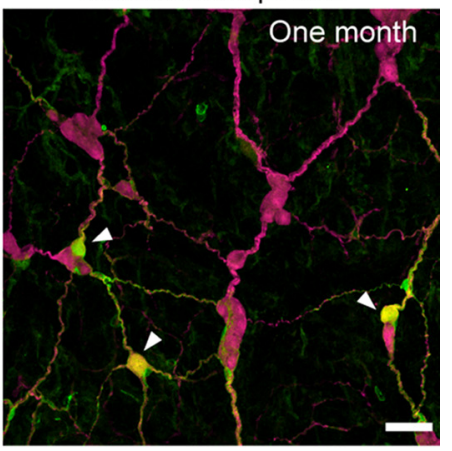

Figure 4. Pattern of colonization by SCPs in the small intestine. $\boldsymbol{A}$, Representative image showing the presence of GFP ${ }^{+}$cells along the extrinsic nerve (Ex) in the mesentery of E14.5 Dhh:::Cre/Gfr $\alpha 7^{f t-G F P /+}$ fetuses $(n=3)$. B. Whole-mount GFP (green) and BLBP (magenta, left) or Phox $2 b$ (right) staining of Dhh::Cre/Gfr $\alpha 7^{f-G F P /+}$ gut $(n=3)$ revealing that GFP ${ }^{+}$cells invading the myenteric plexus at E14.5 express BLBP (a glial marker) but not Phox2b (a marker for progenitor and neuron). C, Representative images of whole-mount GFP (green) and PGP9.5 (magenta) staining of the myenteric, deep muscular, and submucosal plexuses of the small intestine of $D h h::\left(r e / G f r \alpha 7^{f l}-G F P\right.$ mice aged 1 month $(n=4)$. SCPs are barely detectable in the myenteric ganglia (left) but are abundant in the deep muscular plexus (middle). A few GFP-labeled neurons (arrowheads) are present in the submucosal plexus of the small intestine (right). $\boldsymbol{D}$, Schematic showing the colonization pattern of SCP-derived cells in adult small intestine. Scale bars: $A, B, 50 \mu \mathrm{m} ; C, 20 \mu \mathrm{m}$. LM, Longitudinal muscle layers; MP, myenteric plexus; $C M$, circular muscle layers; $S P$, submucosal plexus.

cells expressed glial cell markers, including BLBP and Sox10, but not progenitor/neuronal markers, such as Phox2b and PGP9.5 (Fig. 4B; data not shown). These $\mathrm{GFP}^{+}$cells migrated inward by E15.5 and finally settled in deep muscle and the submucosal layers (Fig. $4 C, D$ ). SCPs were rarely detected in the myenteric ganglia of the small intestine (Fig. 4C,D).

In the large intestine, SCPs were observed along the extrinsic nerve, but not in the gut mesenchyme, at E14.5 (Fig. 5A). By E16.5, the first population of SCPs invaded the gut mesenchyme and expressed BLBP but not Phox 2 b (Fig. $5 B, C$ ). In contrast to the small intestine, SCPs finally populated both the myenteric and submucosal layers (Fig. 5D,E) in the large intestine. By following the fate of SCPs in postnatal animals, we noted the emergence of PGP9.5 ${ }^{+}$neurons in a small subset of $\mathrm{GFP}^{+}$cells at 1 month of age (Figs. $4 C, 5 D$, arrowheads), suggesting that SCP- derived neurogenesis takes place in the gut, which is normally populated by ENCCs.

To reveal the developmental sequence of Dhh::Cre-labeled neuronal precursors, we crossed a Dhh::Cre driver to a $\operatorname{Ret}^{f l-C F P /+}$ reporter line. Ret-expressing cells $\left(\mathrm{CFP}^{+}\right)$become readily discernible by $\mathrm{P} 1$ (Fig. $6 A, B$ ), suggesting that SCPs begin to acquire neuronal phenotype in the perinatal period. Although many of these cells $(\sim 80 \%)$ did not express the neuronal marker PGP9.5 at birth, all of the $\mathrm{CFP}^{+}$cells became PGP9.5 ${ }^{+}$at P21, indicating that neuronal differentiation of Dhh::Cre-labeled cells occurs during the postnatal period. Notably, we did not detect Cre protein expression in any of these $\mathrm{CFP}^{+}$cells during the process of neuronal differentiation, which excludes the possibility of ectopic Cre expression in neuronal cells by the Dhh promoter (Fig. 6C). 
A

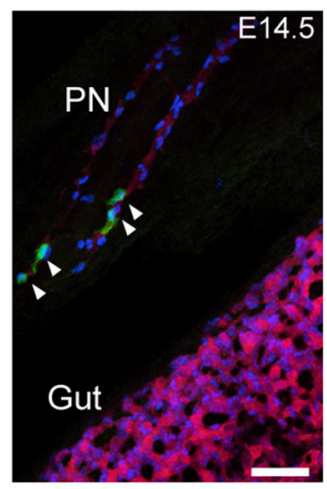

GFP/PGP9.5/Sox10

D

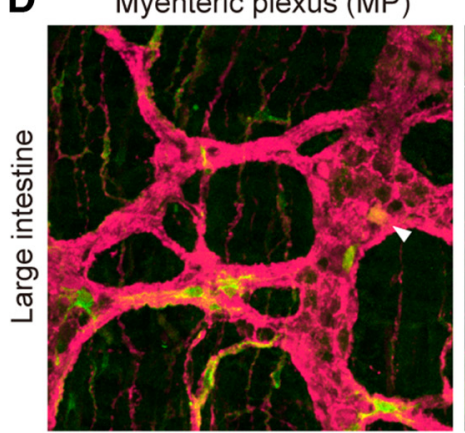

B

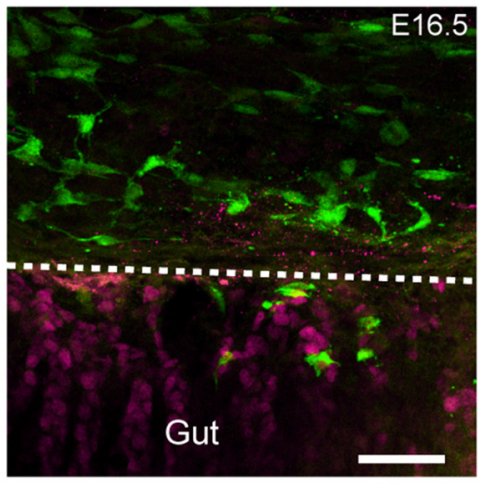

GFP/Phox2b

Submucosal plexus (SP)
C

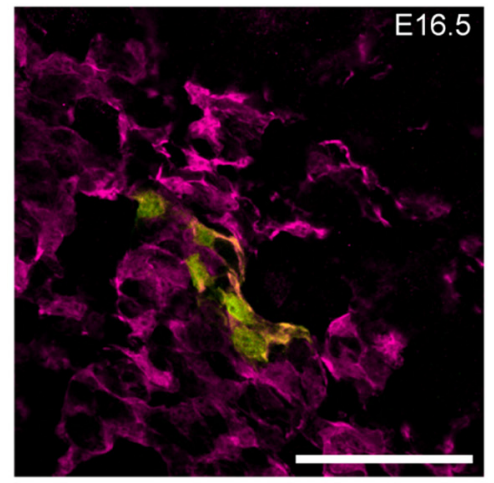

GFP/BLBP

E
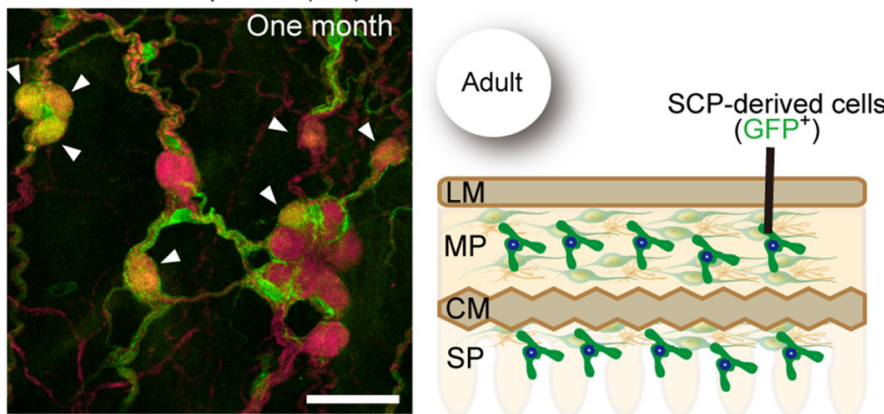

Figure 5. SCPs colonize both the myenteric and submucosal plexuses in the large intestine. $A$, Comparison of colonization pattern between sacral ENCCs and SCPs in the distal colon. SCPs (green, arrowheads), which were labeled by the Dhh::Cre driver, were detected only along the pelvic nerves (PN) in Dhh::(re/Gfr $\alpha f^{f t}-$ GFP embryos (E14.5, $n=3$ ). PGP9.5 staining (red) shows intrinsic ENCC innervation (gut) and the pelvic nerve. Sacral ENCCS were not labeled by the Dhh::Cre driver. B, A representative image showing migration of SCPs from the pelvic nerve to the wall of distal hindgut at E16.5 $(n=3)$. SCPs in the myenteric plexus did not express Phox2b during this period. C, Whole-mount GFP (green) and BLBP (magenta) staining of the large intestine of Dhh:: $\left(r e / G\right.$ fr $\alpha 7^{f l-G P P /+}$ mice $(n=3)$, revealing that GFP ${ }^{+}$cells invading the myenteric plexus at E16.5 express BLBP. D, Localization of SCPs (GFP ${ }^{+}$, green) in the myenteric and submucosal plexuses of the large intestine $(n=3)$ at 1 month. Neuronal cells were visualized by PGP9.5 (magenta) antibodies. Arrowheads indicate GFP ${ }^{+}-\mathrm{PGP9.5}{ }^{+}$neurons. E, Schematic showing the colonization pattern of SCP-derived cells in adult large intestine. Scale bars, $50 \mu \mathrm{m}$. LM, Longitudinal muscle layers; MP, myenteric plexus; CM, circular muscle layers; SP, submucosal plexus.

To further confirm neurogenic potential of SCPs and the absence of Dhh::Cre promoter activity in ENCCs, we immunopurified SCPs and ENCCs, respectively, from the mesentery and the gut of E16.5 Dhh::Cre/Gfr $\alpha 1^{f l-G F P /+}$ embryos and grew those cells in culture. GFP-labeled SCPs initially expressed the glial markers Sox 10 and BLBP (Fig. 7A), but, after $5 \mathrm{~d}$ of plating, a subset of these SCPs began to express the neuronal markers TuJ1 and Phox $2 \mathrm{~b}$ (Figs. $7 B-D$ ). The acquisition of neuronal identity appeared to be saturated by $10 \mathrm{~d}$ in culture (Fig. $7 C$ ). In stark contrast, we detected no GFP expression in ENCC-derived neurons despite that neuronal density of ENCCs was much higher than that of SCPs (Fig. $7 E, F$ ), indicating that Cre is not ectopically expressed in ENCC-derived enteric neurons by the Dhh promoter. Together, these data demonstrate that SCP-derived neurogenesis occurs both in vitro and in vivo.

To assess the contribution of SCPderived neurogenesis to the overall ENS structure, we examined the gut of young adult mice $(\sim 1$ month old) carrying the
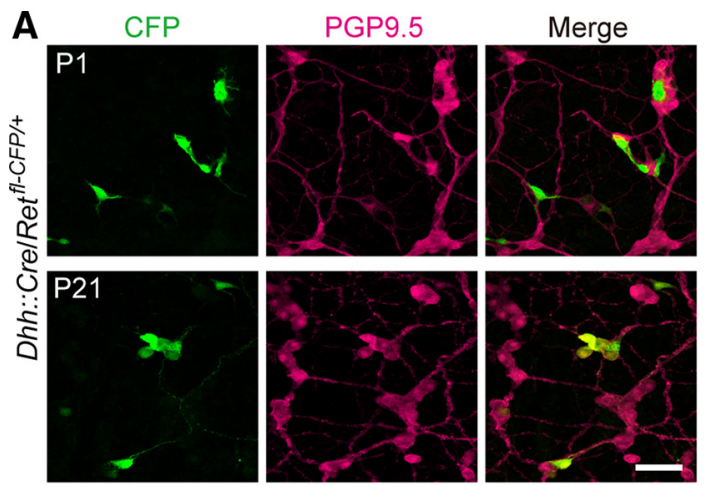

B
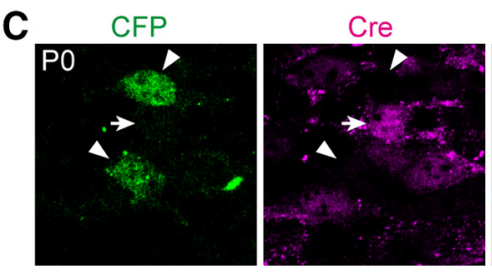

Sox10
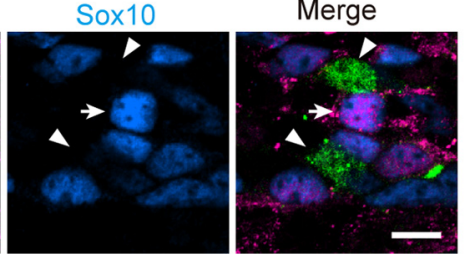

Figure 6. Postnatal neuronal differentiation of SCPs. A, Representative images of whole-mount GFP (green) and PGP9.5 (magenta) staining ofDhh::Cre/Ret ${ }^{f-C F P /+}$ submucosal plexus of the small intestine atP1 and P21.B, Quantification of the fraction of GFP ${ }^{+}$-PGP9.5 ${ }^{+}$ double-positive neurons within the GFP ${ }^{+}$cells in the small intestine at E18.5, P1, and P21 ( $n=3$ animals per group). C, Representative images of whole-mount CFP (Ret ${ }^{+}$) and (re recombinase staining of Dhh:: Cre/Ret $^{f-C F P /+}$ submucosal plexus of the small intestine $(n=3)$. During the period of neuronal differentiation (indicated by the emergence of Ret), no (re recombinase was detected in any of Ret ${ }^{+}$cells. Arrow indicates Cre recombinase detected in Sox $10^{+}$glial cells. Scale bars: $A, 50 \mu \mathrm{m} ; \boldsymbol{C}, 20 \mu \mathrm{m}$. 
A
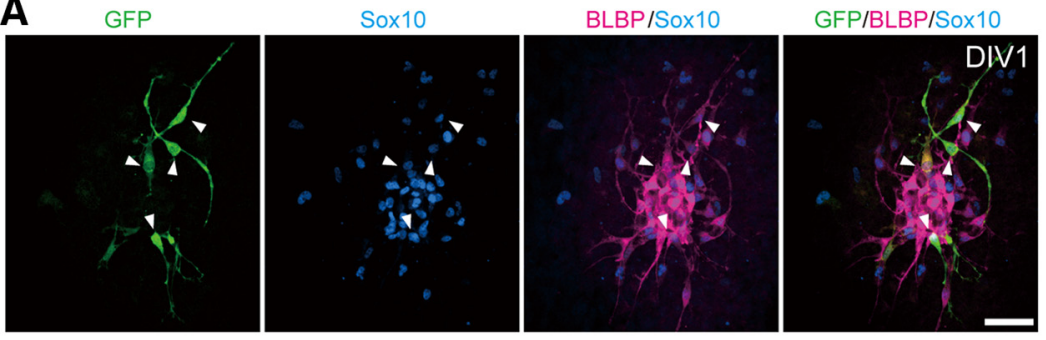

B
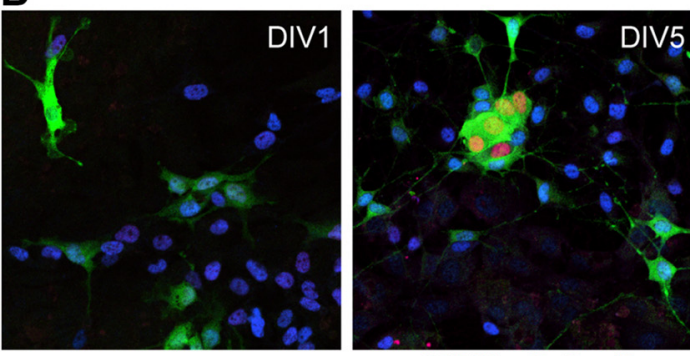

GFP/Phox2b /Sox10

C

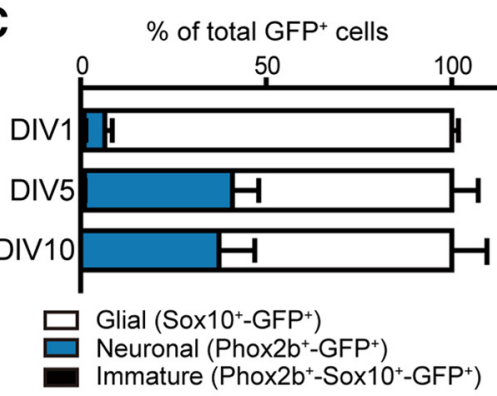

D GFP

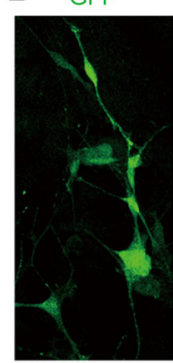

E

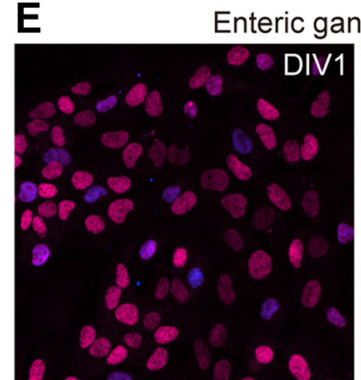

GFP/Phox2b/Sox10

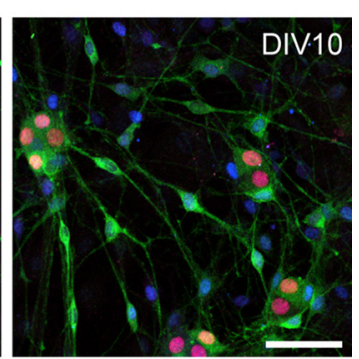

TuJ1/Phox2b Merge
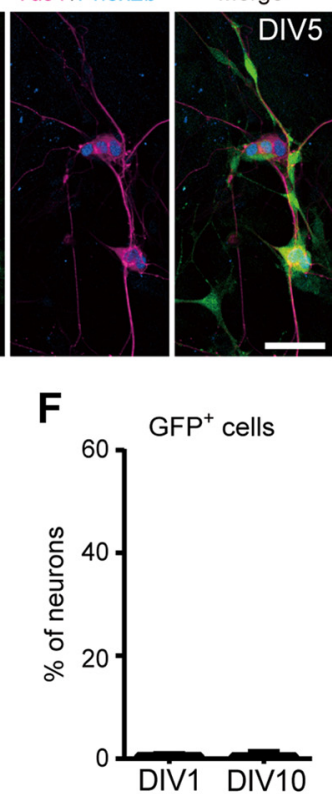

Figure 7. Extrinsic nerve-associated SCPs display neurogenic potential in vitro. A, GFP-labeled cells isolated from the mesentery of E16.5 Dhh:: Cre/Gfr $\alpha 7^{f l}-G F P$ embryos expressed the glial cell markers Sox 10 (blue) and BLBP (magenta) $1 \mathrm{~d}$ after plating [1 $\mathrm{d}$ in vitro (DIV1)]. B, Representative images of cultured cells stained with GFP (green), Sox10 (blue), and Phox2b (magenta) antibodies at 1,5, and $10 \mathrm{~d}$ after plating. At DIV1, most of GFP ${ }^{+}$cells expressed Sox10. At the date of plating, there were very few, if any, $\mathrm{GFP}^{+}$cells expressing Phox2b, a marker for enteric neurons. After $5 \mathrm{~d}$ in culture, a substantial population of GFP ${ }^{+}$cells acquired Phox2b expression (DIV5 and DIV10). C, Quantification of the fraction of neurons, glia, and immature cells in GFP ${ }^{+}$cell populations of DIV1, DIV5, and DIV10 cultures ( $n=4$ experiments; error bars indicate SEM). $D$, Immunostaining by the pan-neuronal marker TuJ1 (magenta) confirmed that GFP ${ }^{+}+$Phox $2 b^{+}{ }^{+}$cells are neurons. E, ENCCs isolated from E16.5 Dhh::Cre/Gfr $\alpha 7^{f l}-$ GFP midgut did not express Dhh::Cre during $10 \mathrm{~d}$ incubations. $\boldsymbol{F}$, Quantification of a GFP ${ }^{+}$neuronal population in ENCC-derived neurons of DIV1 and DIV10 cultures ( $n=3$ experiments; error bars indicate SEM). Scale bars, $50 \mu \mathrm{m}$.

Dhh::Cre transgene and $\operatorname{Ret}^{f l-C F P /+}$ reporter allele. The analysis revealed a substantial contribution by SCP-derived neurons to the enteric ganglia. In the small intestine, SCP-derived neurons constituted up to $5 \%$ of the submucosal ganglion neurons, although their contribution to myenteric ganglia was barely detectable (Fig. $8 A$, left, $B$ ). In contrast, in the large intestine, SCPderived neurons contributed to $20 \%$ of both the myenteric and submucosal neurons (Fig. $8 A$, right, $B$ ). The vast majority of SCPderived neurons expressed calretinin, a marker for excitatory motor neurons, interneurons, and a subset of intrinsic primary afferent neurons (Sang and Young, 1998; Qu et al., 2008), whereas a small proportion $(<12 \%)$ of SCP-derived neurons expressed NOS, a marker for inhibitory motor neurons and interneurons (Lyster et al., 1995; Sang et al., 1997; Fig. 8C,D). Somata of SCPderived neurons were heavily surrounded by presynaptic terminals, suggesting that these neurons were integrated into the ENCC-derived enteric ganglia (Fig. 8E). Collectively, these results identify SCPs as a novel cellular source for the ENS and suggest the role of SCP-derived neurons in the formation of the autonomic ENS circuitry.

To examine the physiological requirement of SCP-derived neurons in the ENS integrity, we conditionally inactivated the Ret gene in a SCP-specific manner. RET signaling is required not only for the development of the ENS but also its postnatal maintenance (Uesaka et al., 2008; Uesaka and Enomoto, 2010). The structure of the ENS was examined in Dhh::Crel $\operatorname{Ret}^{f l-C F P /+}$ (control) and Dhh::Cre/Ret $t^{f-C F P /-}$ (cKO) animals (Fig. 9A). SCP-specific Ret inactivation resulted in a significant decrease in the number of enteric neurons in the terminal portion of the colon of 4-month-old mice (Fig. 9B, $C$ ), indicating that SCP-derived neurogenesis is required for the postnatal maintenance of structural integrity of the ENS.

\section{Discussion}

The ENS is the most complex division of the peripheral nervous system. The human ENS contains several hundred million neurons, whereas the mouse ENS has more than 1 million (Gianino et al., 2003). These are generated by a robust neurogenesis process that persists from midgestation to the postnatal period. Our genetic tracing experiment has revealed, for the first time to our knowledge, that SCPs adopt a neuronal fate in the postnatal period and contribute to the ENS. In the colon, up to $20 \%$ of myenteric and submucosal neurons are of SCP origin. Therefore, SCP-derived neurogenesis underlies a significant portion of postnatal neurogenesis in the ENS. This study also revises the conventional view that enteric neurons are derived solely from ENCCs.

SCP-derived neurogenesis is most substantial in the colon; $\sim 20 \%$ of colonic neurons are derived from SCPs that migrate along the pelvic nerve. This relatively large contribution by SCPs raises a question as to whether SCPs represent a cell population distinct from the sacral ENCCs. A previous study, along with our finding, shows that early migrating sacral NC-derived ENCCs 
express Phox2b and Ret at E13-E14.5 (Anderson et al., 2006). In contrast, SCPs express neither RET nor Phox $2 b$ at the time of gut invasion (E14.5). Thus, sacral ENCCs and SCPs appear to be two distinct cell populations at least at the initial phase of their migration. Recent studies show that the sacral neural crest cells invade the gut via nerve fibers (Wang et al., 2011). Although the exact cellular identity of those cells are unknown, a part of them can be SCPs. Collectively, contribution of the sacral neural crest cells to the ENS may be divided into that of sacral ENCCs and of SCPs, and, given the robust neuronal differentiation of SCPs, SCP-derived neurogenesis may represent a principal sacral contribution to the caudal ENS. However, we must note that SCP-derived neurogenesis is also substantial at the cecum (data not shown), which suggests that SCPs invading the gut associated with nerves other than the pelvic nerve also retains high neurogenic potential. The degrees of neurogenic potential in SCPs associating with distinct extrinsic nerves remain to be elucidated.

SCP-derived neurogenesis is required physiologically in development of the ENS because SCP-specific Ret ablation led to oligoganglionosis of the terminal portion of the colon. These results demonstrate that extrinsic innervation is essential for the structural integrity of the enteric ganglia. They also suggest that gene mutations affecting Schwann cell, not neuronal, lineage cells may contribute to Hirschsprung disease-related ENS disorders. The exact reason that the oligoganglionic region is restricted only to the terminal colon is currently unknown. However, a previous study in which RET signaling was inactivated at distinct developmental time periods showed that, after midgestation, RET disruption causes abnormal cell death in the colon but not in the small intestine. Moreover, reduction in RET expression leads to intestinal aganglionosis only in the terminal portion of the colon (Uesaka et al., 2008). These data suggest that neurons located in more caudal regions of the ENS requires higher levels of RET signaling for their proper development. This caudal-high gradient in RET requirement may also explain our observation that SCP-derived neurons were found in the small intestine but not in the colon of RET-deficient newborn mice.

Classic heterotopic and heterochronic transplantation between chick and quail (Ayer-Le Lievre and Le Douarin, 1982) revealed that satellite glia in immature developing ganglia can be neurogenic when challenged and placed in an ectopic (but favorable) environment. Recent developmental studies in mice demonstrated that cranial nerve-associated bipotent (neuron/glia) progenitors of the parasympathetic ganglia express SCP markers (Dyachuk et al., 2014; Espinosa-Medina et al., 2014), seeming to support the idea of neuronal differentiation by peripheral glial cells. However, all of these cranial nerve-associated bipotent cells initially express both Phox $2 \mathrm{~b}$ and Sox10, a hallmark of nascent autonomic ganglion progenitors (Kim et al., 2003; Young et al., 2003), and thus are defined as uncommitted neural progenitors, not as cells committed to Schwann cell lineage (Jessen and Mirsky, 2005). Therefore, it has remained unanswered whether cells committed to Schwann cell lineage can differentiate into neurons. In this study, we focused on SCPs associated with extrinsic nerves projecting the gut. These SCPs, similar to those found in most regions of the body, express Sox10, but not Phox2b. Our data provide compelling evidence that committed SCPs do retain neurogenic potential for a long term and differentiate into neurons even in the postnatal period. Importantly, during SCPderived neurogenesis, we never detected the emergence of 
A

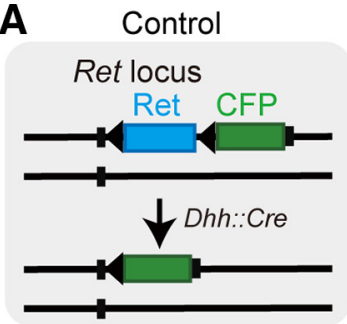

\section{B Control}
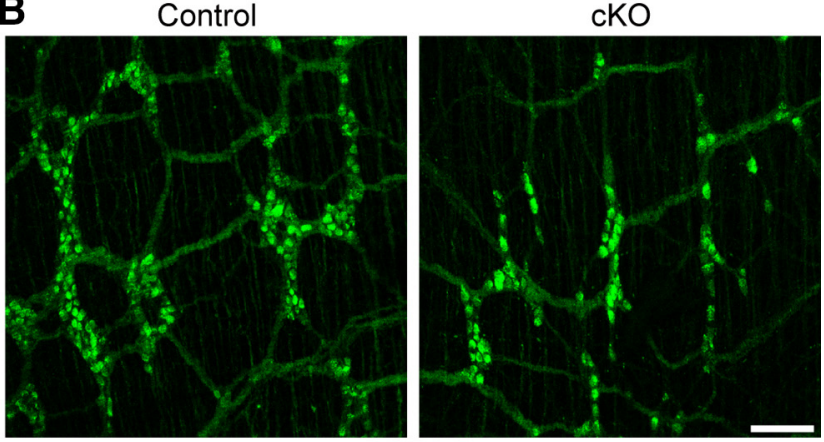

PGP9.5

C

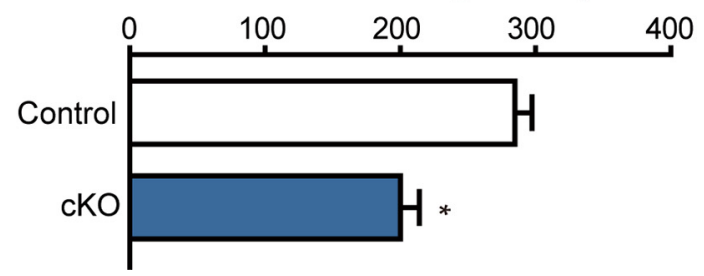

Figure 9. Ret inactivation in SCPs causes hypoganglionosis in the terminal colon. $A$, Schematic showing conditional inactivation of the Ret gene in SCPs by Dhh::Cre. The Ret locus of the control and CKO animals harbors wild-type and null (orange cross) alleles, respectively, in addition to the Ret $^{f l}-$ CFP reporter allele. $\boldsymbol{B}$, Representative images of whole-mount PGP9.5 staining of the distal colon of control and cKO mice aged 4 months. $C$, Quantification of enteric neurons in the terminal colon of control and $\mathrm{K} K 0$ mice at 4 months. Significant differences detected by $t$ test with Welch's correction ( $n=3$ mice from 3 litters; error bars represent SEM; $F_{(2,2)}=1.263$, $\left.{ }^{*} p=0.0204\right)$. Scale bars, $50 \mu \mathrm{m}$.

Sox $10^{+} /$Phox $2 \mathrm{~b}^{+}$bipotent autonomic ganglion progenitors, suggesting that neuronal differentiation of SCPs does not involve a bipotent progenitor state.

Previous reports have shown that SCPs give rise to melanocytes and myofibroblasts in vivo (Joseph et al., 2004; Adameyko et al., 2009), Together with those data, our study reveals the multipotent nature of SCPs and suggests that SCPs are the elusive stem cells that have been reported in various peripheral tissues (Dupin and Sommer, 2012). Although it is unclear whether terminally differentiated Schwann cells retain neurogenic potential, recent works have implicated the possibility that adult Schwann cells are capable of generating neurons in response to environmental changes. In adult ENS, glial cells are recruited to generate neurons in response to neuronal injury and loss (Joseph et al., 2011; Laranjeira et al., 2011). Although definitive identification of this neurogenic glial cell population will require additional study, our findings suggest Schwann cells to be the most likely candidate. Stimulation of 5-hydroxytryptamine receptor $4\left(5-\mathrm{HT}_{4}\right)$ receptor has been shown to promote enteric neurogenesis in adult mice (Liu et al., 2009). Interestingly, ENS precursor-like cells that display $5-\mathrm{HT}_{4}$-induced BrdU incorporation are detected outside of the ganglionic layers and then slowly migrate into ganglia. Although expression of the $5-\mathrm{HT}_{4}$ receptor in Schwann cell lineage remains unclear, it will be worth investigating the involvement of Schwann cell lineage in 5-HT-mediated adult neurogenesis.

Schwann cells are among the most widely distributed types of $\mathrm{NC}$-derived cells, and the physiological significance of their latent multipotency needs to be more thoroughly investigated. It is currently unknown whether SCPs have neurogenic potential in organs other than the ENS. Moreover, dysregulation of multipotency in SCPs or Schwann cells may lead to various neoplasms, such as neuroblastoma, melanoma, lipoma, and primitive neuroectodermal tumor (Takahashi et al., 2013). Our identification of SCPs as a tissue stem cell revises our understanding of the development and disorders of NC-derived organs.

\section{References}

Adameyko I, Lallemend F, Aquino JB, Pereira JA, Topilko P, Müller T, Fritz N, Beljajeva A, Mochii M, Liste I, Usoskin D, Suter U, Birchmeier C, Ernfors P (2009) Schwann cell precursors from nerve innervation are a cellular origin of melanocytes in skin. Cell 139:366-379. CrossRef Medline

Anderson RB, Stewart AL, Young HM (2006) Phenotypes of neural-crestderived cells in vagal and sacral pathways. Cell Tissue Res 323:11-25. CrossRef Medline

Ayer-Le Lievre CS, Le Douarin NM (1982) The early development of cranial sensory ganglia and the potentialities of their component cells studied in quail-chick chimeras. Dev Biol 94:291-310. CrossRef Medline

Bitgood MJ, McMahon AP (1995) Hedgehog and Bmp genes are coexpressed at many diverse sites of cell-cell interaction in the mouse embryo. Dev Biol 172:126-138. CrossRef Medline

Branchek TA, Gershon MD (1989) Time course of expression of neuropeptide $\mathrm{Y}$, calcitonin gene-related peptide, and NADPH diaphorase activity in neurons of the developing murine bowel and the appearance of 5-hydroxytryptamine in mucosal enterochromaffin cells. J Comp Neurol 285:262-273. CrossRef Medline

Druckenbrod NR, Epstein ML (2005) The pattern of neural crest advance in the cecum and colon. Dev Biol 287:125-133. CrossRef Medline

Dupin E, Sommer L (2012) Neural crest progenitors and stem cells: from early development to adulthood. Dev Biol 366:83-95. CrossRef Medline

Durbec PL, Larsson-Blomberg LB, Schuchardt A, Costantini F, Pachnis V (1996) Common origin and developmental dependence on c-ret of subsets of enteric and sympathetic neuroblasts. Development 122:349-358. Medline

Dyachuk V, Furlan A, Shahidi MK, Giovenco M, Kaukua N, Konstantinidou C, Pachnis V, Memic F, Marklund U, Müller T, Birchmeier C, Fried K, Ernfors P, Adameyko I (2014) Neurodevelopment. Parasympathetic neurons originate from nerve-associated peripheral glial progenitors. Science 345:82-87. CrossRef Medline

Enomoto H, Araki T, Jackman A, Heuckeroth RO, Snider WD, Johnson EM Jr., Milbrandt J (1998) GFR a1-deficient mice have deficits in the enteric nervous system and kidneys. Neuron 21:317-324. CrossRef Medline

Espinosa-Medina I, Outin E, Picard CA, Chettouh Z, Dymecki S, Consalez GG, Coppola E, Brunet JF (2014) Neurodevelopment. Parasympathetic ganglia derive from Schwann cell precursors. Science 345:87-90. CrossRef Medline

Gianino S, Grider JR, Cresswell J, Enomoto H, Heuckeroth RO (2003) GDNF availability determines enteric neuron number by controlling precursor proliferation. Development 130:2187-2198. CrossRef Medline

Gould TW, Yonemura S, Oppenheim RW, Ohmori S, Enomoto H (2008) The neurotrophic effects of glial cell line-derived neurotrophic factor on spinal motoneurons are restricted to fusimotor subtypes. J Neurosci 28: 2131-2146. CrossRef Medline

Jaegle M, Ghazvini M, Mandemakers W, Piirsoo M, Driegen S, Levavasseur F, Raghoenath S, Grosveld F, Meijer D (2003) The POU proteins Brn-2 and Oct- 6 share important functions in Schwann cell development. Genes Dev 17:1380-1391. CrossRef Medline

Jain S, Golden JP, Wozniak D, Pehek E, Johnson EM Jr, Milbrandt J (2006) RET is dispensable for maintenance of midbrain dopaminergic neurons in adult mice. J Neurosci 26:11230-11238. CrossRef Medline

Jessen KR, Mirsky R (2005) The origin and development of glial cells in peripheral nerves. Nat Rev Neurosci 6:671-682. CrossRef Medline

Joseph NM, Mukouyama YS, Mosher JT, Jaegle M, Crone SA, Dormand EL, Lee KF, Meijer D, Anderson DJ, Morrison SJ (2004) Neural crest stem 
cells undergo multilineage differentiation in developing peripheral nerves to generate endoneurial fibroblasts in addition to Schwann cells. Development 131:5599-5612. CrossRef Medline

Joseph NM, He S, Quintana E, Kim YG, Núñez G, Morrison SJ (2011) Enteric glia are multipotent in culture but primarily form glia in the adult rodent gut. J Clin Invest 121:3398-3411. CrossRef Medline

Kim J, Lo L, Dormand E, Anderson DJ (2003) SOX10 maintains multipotency and inhibits neuronal differentiation of neural crest stem cells. Neuron 38:17-31. CrossRef Medline

Laranjeira C, Sandgren K, Kessaris N, Richardson W, Potocnik A, Vanden Berghe P, Pachnis V (2011) Glial cells in the mouse enteric nervous system can undergo neurogenesis in response to injury. J Clin Invest 121:3412-3424. CrossRef Medline

Le Douarin N, Kalcheim C (1999) The neural crest, Ed 2. Cambridge, UK: Cambridge UP.

Le Douarin NM, Teillet MA (1973) The migration of neural crest cells to the wall of the digestive tract in avian embryo. J Embryol Exp Morphol 30: 31-48. Medline

Liu MT, Kuan YH, Wang J, Hen R, Gershon MD (2009) 5-HT4 receptormediated neuroprotection and neurogenesis in the enteric nervous system of adult mice. J Neurosci 29:9683-9699. CrossRef Medline

Lyster DJ, Bywater RA, Taylor GS (1995) Neurogenic control of myoelectric complexes in the mouse isolated colon. Gastroenterology 108:1371-1378. CrossRef Medline

Nishiyama C, Uesaka T, Manabe T, Yonekura Y, Nagasawa T, Newgreen DF, Young HM, Enomoto H (2012) Trans-mesenteric neural crest cells are the principal source of the colonic enteric nervous system. Nat Neurosci 15:1211-1218. CrossRef Medline

Obermayr F, Hotta R, Enomoto H, Young HM (2013) Development and developmental disorders of the enteric nervous system. Nat Rev Gastroenterol Hepatol 10:43-57. CrossRef Medline

Parmantier E, Lynn B, Lawson D, Turmaine M, Namini SS, Chakrabarti L, McMahon AP, Jessen KR, Mirsky R (1999) Schwann cell-derived Desert hedgehog controls the development of peripheral nerve sheaths. Neuron 23:713-724. CrossRef Medline

Pham TD, Gershon MD, Rothman TP (1991) Time of origin of neurons in the murine enteric nervous system: sequence in relation to phenotype. J Comp Neurol 314:789-798. CrossRef Medline

Qu ZD, Thacker M, Castelucci P, Bagyánszki M, Epstein ML, Furness JB (2008) Immunohistochemical analysis of neuron types in the mouse small intestine. Cell Tissue Res 334:147-161. CrossRef Medline

Rothman TP, Gershon MD (1982) Phenotypic expression in the developing murine enteric nervous system. J Neurosci 2:381-393. Medline

Rothman TP, Gershon MD (1984) Regionally defective colonization of the terminal bowel by the precursors of enteric neurons in lethal spotted mutant mice. Neuroscience 12:1293-1311. CrossRef Medline

Sang Q, Young HM (1998) The identification and chemical coding of cholinergic neurons in the small and large intestine of the mouse. Anat Rec 251:185-199. CrossRef Medline

Sang Q, Williamson S, Young HM (1997) Projections of chemically identi- fied myenteric neurons of the small and large intestine of the mouse. J Anat 190:209-222. CrossRef Medline

Takahashi Y, Sipp D, Enomoto H (2013) Tissue interactions in neural crest cell development and disease. Science 341:860-863. CrossRef Medline

Taraviras S, Marcos-Gutierrez CV, Durbec P, Jani H, Grigoriou M, Sukumaran M, Wang LC, Hynes M, Raisman G, Pachnis V (1999) Signalling by the RET receptor tyrosine kinase and its role in the development of the mammalian enteric nervous system. Development 126:2785-2797. Medline

Uesaka T, Enomoto H (2010) Neural precursor death is central to the pathogenesis of intestinal aganglionosis in Ret hypomorphic mice. J Neurosci 30:5211-5218. CrossRef Medline

Uesaka T, Jain S, Yonemura S, Uchiyama Y, Milbrandt J, Enomoto H (2007) Conditional ablation of GFR $\alpha 1$ in postmigratory enteric neurons triggers unconventional neuronal death in the colon and causes a Hirschsprung's disease phenotype. Development 134:2171-2181. CrossRef Medline

Uesaka T, Nagashimada M, Yonemura S, Enomoto H (2008) Diminished Ret expression compromises neuronal survival in the colon and causes intestinal aganglionosis in mice. J Clin Invest 118:1890-1898. CrossRef Medline

Uesaka T, Nagashimada M, Enomoto H (2013) GDNF signaling levels control migration and neuronal differentiation of enteric ganglion precursors. J Neurosci 33:16372-16382. CrossRef Medline

Wang H, Hughes I, Planer W, Parsadanian A, Grider JR, Vohra BP, KellerPeck C, Heuckeroth RO (2010) The timing and location of glial cell line-derived neurotrophic factor expression determine enteric nervous system structure and function. J Neurosci 30:1523-1538. CrossRef Medline

Wang X, Chan AK, Sham MH, Burns AJ, Chan WY (2011) Analysis of the sacral neural crest cell contribution to the hindgut enteric nervous system in the mouse embryo. Gastroenterology 141:992-1002.e1-6. CrossRef Medline

Widera D, Heimann P, Zander C, Imielski Y, Heidbreder M, Heilemann M, Kaltschmidt C, Kaltschmidt B (2011) Schwann cells can be reprogrammed to multipotency by culture. Stem Cells Dev 20:2053-2064. CrossRef Medline

Wong CE, Paratore C, Dours-Zimmermann MT, Rochat A, Pietri T, Suter U, Zimmermann DR, Dufour S, Thiery JP, Meijer D, Beermann F, Barrandon Y, Sommer L (2006) Neural crest-derived cells with stem cell features can be traced back to multiple lineages in the adult skin. J Cell Biol 175:1005-1015. CrossRef Medline

Young HM, Jones BR, McKeown SJ (2002) The projections of early enteric neurons are influenced by the direction of neural crest cell migration. J Neurosci 22:6005-6018. Medline

Young HM, Bergner AJ, Müller T (2003) Acquisition of neuronal and glial markers by neural crest-derived cells in the mouse intestine. J Comp Neurol 456:1-11. CrossRef Medline

Young HM, Bergner AJ, Anderson RB, Enomoto H, Milbrandt J, Newgreen DF, Whitington PM (2004) Dynamics of neural crest-derived cell migration in the embryonic mouse gut. Dev Biol 270:455-473. CrossRef Medline 